\title{
Hydrologic nonstationarity and extrapolating models to predict the future: overview of session and proceeding
}

\author{
F. H. S. Chiew and J. Vaze \\ CSIRO Land and Water Flagship, GPO Box 1666, Canberra, ACT 2601, Australia \\ Correspondence to: F. H. S. Chiew (francis.chiew@ csiro.au)
}

Received: 18 March 2015 - Accepted: 18 March 2015 - Published: 12 June 2015

\begin{abstract}
This paper provides an overview of this IAHS symposium and PIAHS proceeding on "hydrologic nonstationarity and extrapolating models to predict the future". The paper provides a brief review of research on this topic, presents approaches used to account for nonstationarity when extrapolating models to predict the future, and summarises the papers in this session and proceeding.
\end{abstract}

\section{Hydrologic nonstationarity and implications - Overview}

The commentary by Milly et al. (2008) has initiated significant discussions and continuing progression of research on hydrologic nonstationarity. The term "hydrologic nonstationarity" has been used to describe many things, ranging from different climate-runoff relationships evident in different periods within a long hydroclimate time series to changes in hydroclimate characteristics and dominant hydrological processes in an increasingly warmer and higher $\mathrm{CO}_{2}$ world. Hydrologists have always represented stationarity and nonstationarity (which is difficult to distinguish statistically in natural systems) as best they could and their implications on water resources and related systems, but modelling this adequately will become increasingly challenging in a world driven by anthropogenic changes.

The constancy of laws and patterns has always been and will always be "stationary". It is our understanding or lack of these and the constancy of variables or characteristics at different times that may appear "nonstationary". For example, a hydroclimate time series can be considered "stationary" over thousands or millions of years, in that we can represent statistically or stochastically the characteristics and variability over time and space scales or even develop a precise understanding of the processes from the very long record. But of course, the characteristics of the different periods will always be different (exhibiting variability over different time and space scales), that is, nonstationary over time. The practical issue then is not whether hydroclimate systems are station- ary or nonstationary, but whether the nonstationarity is substantial enough to require a change in existing system characterisation, conceptualisation or modelling for a particular hydrologic design, operation and planning.

Hydrologists have excelled in developing models for numerous applications, through analysing and interpreting climate and hydrologic data to understand hydrologic processes, conceptualising the processes in hydrological models, and calibrating and testing models against observations. These models are particularly good in predicting the streamflow response to changes in the climate inputs and catchment characteristics. These models, when developed adequately using relatively long historical records that encapsulate the range of hydroclimate conditions, should be able to predict hydrologic responses to changes in the climate inputs over the near and medium term.

However, extrapolating hydrological models to predict further into the future that is influenced by anthropogenic change is challenging as we will then be predicting system behaviours that are beyond the range of observed variability in the instrumental record (changed rainfall characteristics, higher temperature, higher $\mathrm{CO}_{2}$ ) or that result from significant alterations of the physical system characteristics. Therefore, whilst near-term future projections of water availability (and streamflow, hydrological fluxes and stores) are influenced mainly by the large uncertainty in the rainfall projections (Teng et al., 2012), water projections further into the future will be increasingly influenced also by the uncertainty in hydrological modelling. 
Annual temperature, rainfall and runoff time series averaged across far south-eastern Australia highlighting inter-annual and inter-decadal variability and the 1997-2009 Millennium drought
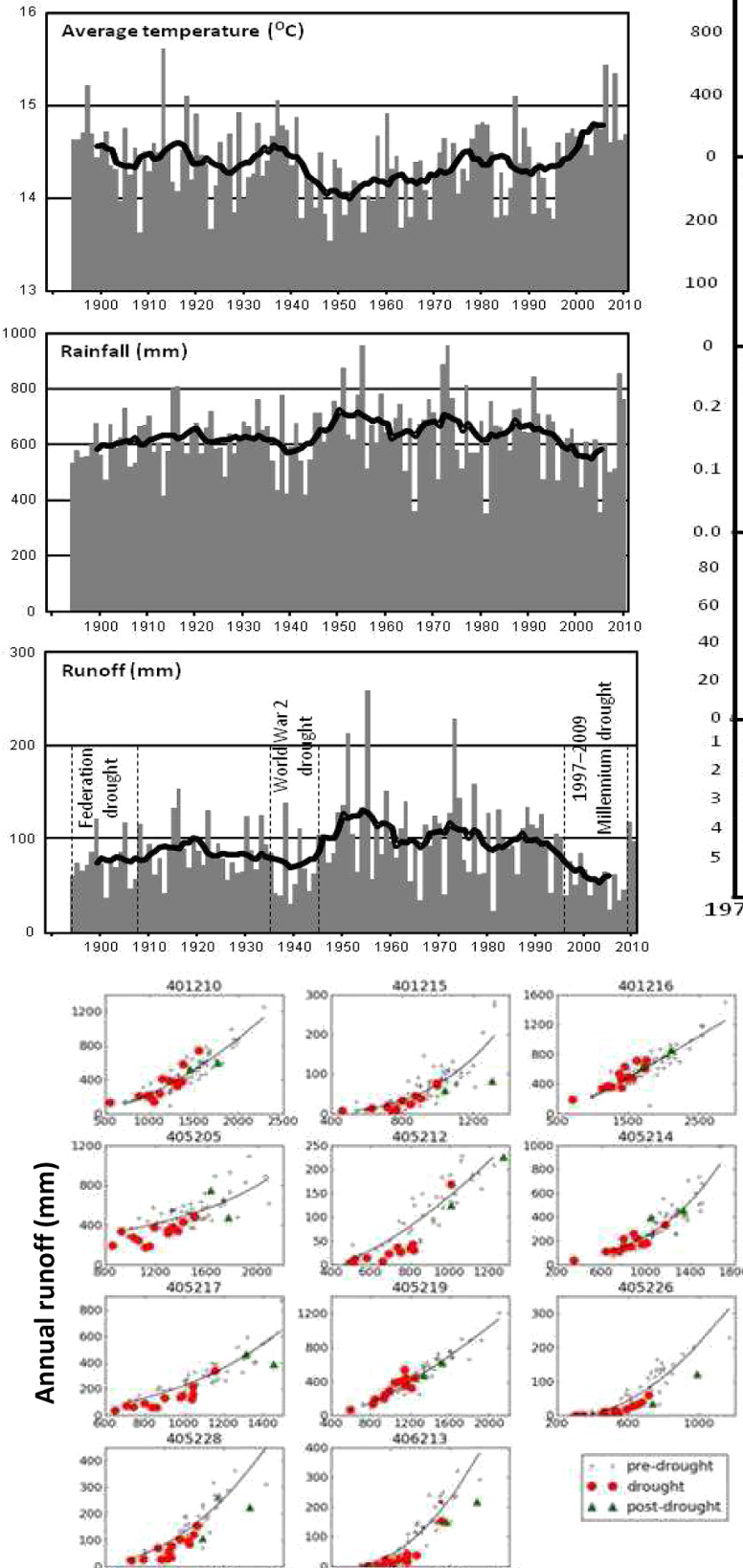

Annual rainfall (mm)
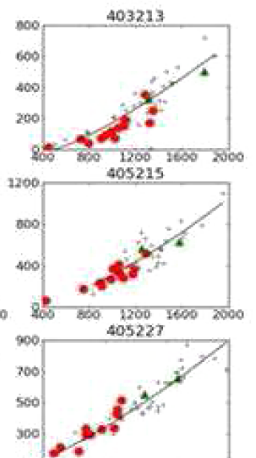

Time series of hydrologic metrics for a catchment in the region highlighting the impact of the 1997-2009 Millennium drought

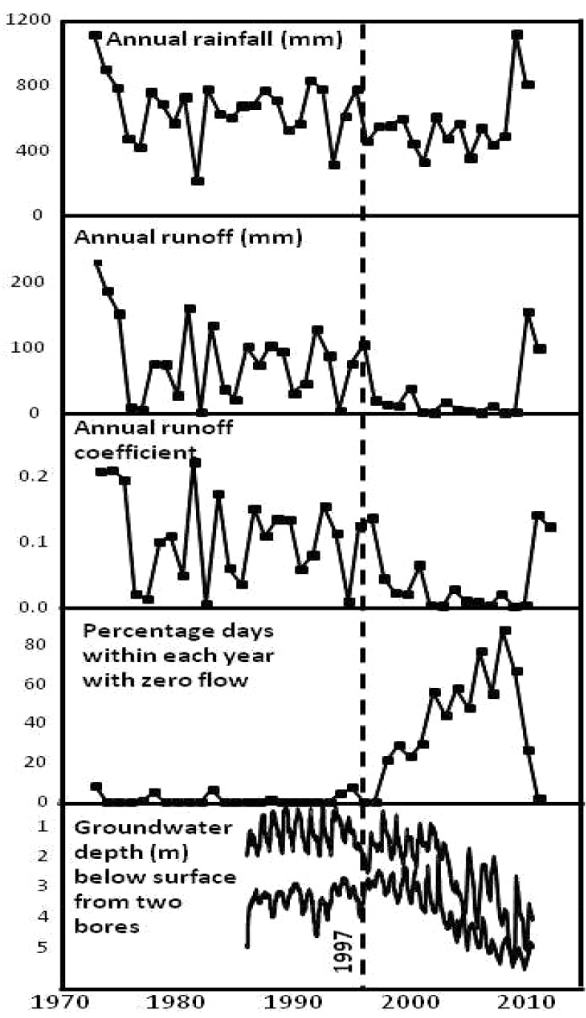

Significant differences in pre-1997 and 19972009 runoff-rainfall relationship in many but not all catchments, depending on degree of surface-groundwater connectivity influenced by climate, terrain and other characteristics

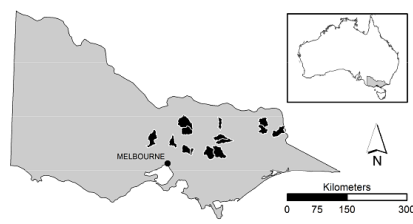

Figure 1. The Millennium Drought in far south-eastern Australia and its influence on hydrology and climate-runoff relationship. 
Chiew et al. (2014) presents an example of hydrologic nonstationarity and the implications on hydrologic prediction exposed by the prolonged 1997-2009 Millennium Drought in far south-eastern Australia (Fig. 1). The unprecedented runoff decline during the drought was caused not only by the lower annual rainfall, but also by changes in other climate characteristics (lack of high rainfall years, change in rainfall seasonality and higher temperatures) and dominant hydrological processes (reduced surface-groundwater connection and farm dams intercepting proportionally more water during dry periods). Because of the significantly different climate-runoff relationship and model conceptualisations that do not adequately represent surface-groundwater connection through long dry spells, it is not surprising then that models developed and calibrated against the pre-1997 data were not able to estimate the flow volumes and runoff characteristics during the drought. However, because the Millennium Drought has exposed these extreme conditions, models can now be developed or adapted to also represent these conditions.

There are many similar examples of models not being able to simulate the hydrology of a period with very different hydroclimate characteristics from the period used to develop the models. However, when the models are developed or calibrated using a long data set that encapsulates the different hydroclimate characteristics of different data periods, the models can generally reasonably simulate the hydrology through the different times (although not as well as if the model was calibrated only against data from the period it is simulating) (Vaze et al., 2010; Merz et al., 2011; Coron et al., 2012). Therefore, following on from the above Millennium Drought example, hydrological models developed and tested against long historical records are generally reliable until there is a significantly 'changed' condition (like the Millennium Drought). After the changed hydroclimate conditions have been observed (following the end of the Millennium Drought), new conceptualisations can be introduced to the models to also represent these conditions. These newly developed models will then continue to be robust until there is another significant and unexpected changed condition. As we can never have a perfect and complete understanding of the ecohydroclimatological processes and interactions, this future prediction problem can only be overcome if we can anticipate all the plausible changes and conceptualise them adequately in models.

\section{Extrapolating hydrological models to predict the future}

With anthropogenic climate change, we know we will at the very least be extrapolating hydrological models to predict a future under changed rainfall distribution and characteristics, warmer conditions and higher $\mathrm{CO}_{2}$. Changes in rainfall characteristics may trigger a change to a hydrologic regime not seen in the past (Grayson and Bloschl, 2000; Peterson et al., 2009; the surface-groundwater connection example earlier). Higher temperatures will influence evapotranspiration and energy and water balance and interactions at different scales (Roderick et al., 2009; Lockart et al., 2009; Potter and Chiew, 2011), and in high altitudes and latitudes change the timing of snowmelt (Woo et al., 2008) and the importance of rain-on-snow rainfall events (Sui and Koehler, 2001). Higher $\mathrm{CO}_{2}$ will reduce canopy conductance and increase leaf water use efficiency $\left(\mathrm{CO}_{2}\right.$ fertilisation) which could be offset by increased leaf area and forest biomass (Medlyn et al., 2001; Betts et al., 2007; Ainsworth and Rogers, 2007; Cheng et al., 2014). However, understanding these potential influences and the complex ecohydrology and atmospheric interactions and feedbacks under higher temperature and $\mathrm{CO}_{2}$ is very difficult and is a significant area of current science and global research programs. In addition, any understanding, speculation or modelling of the physical processes can only be validated against past data, which will then be extrapolated to predict a future that will be significantly different from the past.

"Stationarity is dead". However, it is not apparent what if any alternative methods should be used as a replacement for the different types of hydrological applications. For example, existing approaches may be sufficient for operational water management and short-term planning, but key aspects of "nonstationarity" must be taken into account for certain hydrologic design and long-term planning. Predicting the future is difficult if not impossible, and hydrologic planning will always consider probabilistic or multiple plausible realisations and adopt adaptive risk management with systems planned for particular levels of security or reliability.

Hydrologists have used a variety of approaches to predict a future under nonstationarity. Hydrologic responses to changed climate inputs are generally modelled using hydrological models informed by climate projections from the large or entire range of global and regional climate models (Xu et al., 2005; Christensen and Lettenmaier, 2007; Raisanan, 2007; Chiew et al., 2009; Vaze et al., 2011). Improved understanding of vegetation behaviour and hydrological responses to warmer climate and enhanced $\mathrm{CO}_{2}$ are increasingly incorporated to the more complex hydrological models (Arora, 2002; Murray et al., 2011). Improved conceptualisations are being introduced to hydrological models, particularly where they are used in studies predicting into the future under prolonged extreme conditions. Examples include attempts at parameterising semidistributed hydrological models or adapting existing models to simulate processes important under extreme conditions like long dry spells (farm dam interception (Nathan et al., 2005) and surface-groundwater connectivity (Puspalatha et al., 2011)) and learning from catchments experiencing different or changing conditions (Wagener, 2007; Fenicia et al., 2008; Buytaert and Beven, 2009). Many studies use existing models, but with smart approaches to parameterise and cal- 
ibrate the model, for example (i) with time varying parameters dependent on storage levels (Smith et al., 2008; Merz et al., 2011); (ii) multi-criteria optimisation that also considers low flow simulations (Madsen, 2000; Oudin et al., 2006; Efstratiadis and Koutsoyiannis, 2010); and (iii) predicting the future with parameters from model calibration against a similar climate period as the future climate projections.

Hydrological modelling under changing conditions is a problem familiar in hydrology. This is highlighted by the two decadal initiatives of the International Association of Hydrological Sciences (IAHS), the 2003-2012 Decade on "Prediction in Ungauged Basin" (PUB) focussed on extrapolating model parameterisation in space (Sivapalan et al., 2003; Bloschl et al., 2013) and the "2013-2022 Decade on Panta Rhei - Change in Hydrology and Society" now focussing on prediction in a changing world (extrapolation in time) (Montanari et al., 2013). There have been several useful technical overviews and commentaries on hydrological prediction under change and these include Clifford (2002), Wagener et al. (2010) and Peel and Bloschl (2011). The Colorado State University (2010) workshop on hydrologic nonstationarity and sessions in key international forums (e.g. AGU Fall Meeting 2012, IAHS Assembly 2013) also provides useful discussions on this issue and practical approaches to account for nonstationarity when extrapolating models to predict the future for design, operation and planning of water resources and related systems.

\section{IAHS Symposium and PIAHS Proceeding}

This IAHS symposium on "hydrologic nonstationarity and extrapolating models to predict the future" directly addresses a key issue in the IAHS Panta Rhei Decade (Change in Hydrology and Society) and builds on previous forums on this topic. The presentations (oral and poster) and dedicated discussions in the symposium are focussed on recent advances in hydrologic nonstationarity research and implications on hydrologic predictions.

There are 54 abstracts and 35 full papers accepted for the symposium. This PIAHS proceeding presents the 35 full papers. The papers can be broadly grouped into four categories: (i) papers that characterise hydroclimate trend and nonstationarity and discuss their implications on hydrologic predictions; (ii) papers that largely model climate change impact on water; (iii) papers that explore approaches to take into account hydrologic nonstationarity in predicting the future (through process conceptualisation and/or smart parameterisation of existing models); and (iv) papers that address anthropogenic nonstationarity from catchment development, river regulation and environmental disturbances.

\section{References}

Ainsworth, E. A. and Rogers, A.: The response of photosynthesis and stomatal conductance to rising $\mathrm{CO}_{2}$ : mechanisms and environmental interactions, Plant. Cell Environ., 30, 258-270, doi:10.1111/j.1365-3040.2007.01641.x, 2007.

Arora, V.: Modelling vegetation as a dynamic component in soilvegetation-atmosphere transfer schemes and hydrological models, Rev. Geophys., 40, 3-1-3-26, doi:10.1029/2001RG000103, 2002.

Betts, R. A., Boucher, O., Collins, M., Cox, P. M., Falloon, P. D., Betts, N., Hemming, D. L., Huntingford, C., Jones, C. D., Sexton, D. M. H., and Webb, M. J.: Projected increase in continental runoff due to plant response to increasing carbon dioxide, Nature, 448, 1037-1041, doi:10.1038/nature06045, 2007.

Bloschl, G., Sivapalan, M. Wagener, T., Viglione, A., and Savenjie, H. (Eds.): Runoff Prediction in Ungauged Basins: Synthesis across Processes, Places and Scales, Cambridge University Press, 462 pp., 2013.

Buytaert, W. and Beven, K.: Regionalisation as a learning process, Water Resour. Res., 45, W11419, doi:10.1029/2008WR007359, 2009.

Cheng, L., Zhang, L., Wang, Y. P., Yu, Q., Eamus, D., and O'Grady, A.: Impacts of elevated $\mathrm{CO}_{2}$, climate change and their interactions in four different catchments in Australia, J. Hydrol., 519, 1350-1361, doi:10.1016/j.jhydrol.2014.09.020, 2014.

Chiew, F. H. S., Teng, J., Vaze, J., Post, D. A., Perraud, J.-M., Kirono, D. G. C., and Viney, N. R.: Estimating climate change impact on runoff across south-east Australia: method, results and implications of modelling method, Water Resour. Res., 45, W10414, doi:10.1029/2008WR007338, 2009.

Chiew, F. H. S., Potter, N. J., Vaze, J., Petheram, C., Zhang, L., Teng, J., and Post, D. A.: Observed hydrologic non-stationarity in far south-eastern Australia: implications and future modelling predictions, Stoch. Environ. Res. Risk Assess., 28, 3-15, doi:10.1007/s00477-013-0755-5, 2014.

Christensen, N. S. and Lettenmaier, D. P.: A multimodel ensemble approach to assessment of climate change impacts on the hydrology and water resources of the Colorado River Basin, Hydrol. Earth Syst. Sci., 11, 1417-1434, doi:10.5194/hess-11-14172007, 2007.

Clifford, N. J.: Hydrology: the changing paradigm, Prog. Phys. Geogr., 26, 290-301, doi:10.1191/0309133302pp337pr, 2002.

Colorado State University: Workshop on Nonstationarity, Hydrologic Frequency Analysis and Water Management, Colorado Water Institute, Information Series 109, 304 pp., 2010.

Coron, L., Andreassian, V., Perrin, C., Lerat, J., Vaze, J., Bourqui, M., and Hendrickx, F.: Crash testing hydrological models in contrasted climate conditions: an experiment on 216 Australian catchments, Water Resour. Res., 48, W05552, doi:10.1029/2011WR011721, 2012.

Efstratiadis, A. andKoutsoyiannis, D.: One decade of multiobjective calibration approaches in hydrological modelling: a review, Hydrol. Sci. J., 55, 58-78, 2010.

Fenicia, F., McDonnell, J. J., and Savenije, H. H. G. : Learning from model improvement: on the contribution of complementary data to process understanding, Water Resour. Res., 44, W06419, doi:10.1029/2007WR006386, 2008. 
Grayson, R. G. and Bloschl, G.: Spatial processes, organisations and patterns, in: Spatial Patterns in Catchment Hydrology: Observations and Modelling, edited by: Grayson, R. G. and Bloschl, G., Cambridge University Press, 3-16, 2000.

Lockart, N., Kavetsi, D., and Franks, S. W.: On the recent warming in the Murray-Darling Basin: land surface interactions misunderstood, Geophys. Res. Lett., 36, L24405, doi:10.1029/2009GL040598, 2009.

Madsen, H.: Automatic calibration of a conceptual rainfall-runoff model using multiple objectives, J. Hydrol., 235, 276-288, 2000.

Medlyn, B. E., Barton, C. V. M., Broadmeadow, M. S. J., Ceulemans, R., De Angelis, P., Forstreuter, M., Freeman, M., Jackson, S. B., Kellomaki, S., Laitat, E., Rey, A., Robertntz, P., Sigurdsson, B. D., Strassemeyer, J., Wang, K., Curtis, P. S., and Jarvis, P. G.: Stomatal conductance of forest species after long-term exposure to elevated $\mathrm{CO}_{2}$ concentrations: a synthesis, New Phytol., 149, 247-264, doi:10.1046/j.1469-8137.2001.00028.x, 2001.

Merz, R., Parajka, J., and Bloschl, G.: Time stability of catchment model parameters - implications for climate impact analyses, Water Resour. Res., 47, W02531, doi:10.1029/2010WR009505, 2011.

Milly, P. C. D., Betancourt, J., Falkenmark, M., Hirsch, R. M., Kundzewicz, Z. W., Lettenmaier, D. P., and Stouffer, R. J.: Stationary is dead: whither water management?, Science, 319, 573574,2008

Montanari, A., Young, G., Savinije, H. H. G., Hughes, D., Wagener, T., Ren, L. L., Koutsoyiannis, D., Cudennec, C., Toth, E., Grimaldi, S., Bloschl, G., Sivapalan, M., Beven, K., Gupta, H., Hipsey, M., Schaefli, B., Arheimer, B., Boegh, E., Schymanski, S. J., Di Baldassarre, G., Yu, B., Hubert, P., Huang, Y., Schumann, A., Post, D. A., Srinivasan, V., Harman, C., Thompson, S., Rogger, M., Viglione, A., McMillan, H., Characklis, G., Pang, Z., and Belyaev, V.: "Panta-Rhei - Everything Flows": Change in hydrology and society - The IAHS Scientific Decade 20132022, Hydrol. Sci. J., 58, 1256-1275, 2013.

Murray, S. J., Foster, P. N., and Prentice, I. C.: Evaluation of global continental hydrology as simulated by the Land-surface Processes and eXchanges Dynamic Global Vegetation Model, Hydrol. Earth Syst. Sci., 15, 91-105, doi:10.5194/hess-15-91-2011, 2011.

Nathan, R. J., Phillip, J., and Morden, R.: Assessing the impact of farm dams on streamflows, Part 1, Development of simulation tools, Aust. J. Water Resour., 9, 1-12, 2005.

Oudin, L., Andreassian, V., Mathevet, T., Perrin, C., and Michel, C.: Dynamic averaging of rainfall-runoff model simulations from complementary model parameterisations, Water Resour. Res., 42, W07410, doi:10.1029/2005WR004636, 2006.

Peel, M. C. \& Bloschl, G.: Hydrological modelling in a changing world, Prog. Phys. Geogr., 35, 249-261, doi:10.1177/0309133311402550, 2011.

Peterson, T. J., Argent, R. M., Western, A. W., and Chiew, F. H. S.: Multiple stable states in hydrological models: an ecohydrological investigation, Water Resour. Res., 45, W03406, doi:10.1029/2008WR006886, 2009.
Potter, N. J. and Chiew, F. H. S.: An investigation into changes in climate characteristics causing the recent very low runoff in the southern Murray-Darling Basin using rainfall-runoff models, Water Resour. Res., 47, W00G10, doi:10.1029/2010WR010333, 2011.

Puspalatha, R., Perrin, C., Le Moine, N., Mathevet, T., and Andreassian, V.: A downward structural sensitivity analysis of hydrological models to improve low-flow simulation, J. Hydrol., 411, 6676, doi:10.1016/j.jhydrol.2011.09.034, 2011.

Raisanan, J.: How reliable are climate models?, Tellus, 59A, 2-29, doi:10.1111/j.1600-0870.2006.00211.x, 2007.

Roderick, M. L., Hobbins, M. T., and Farquhar, G. D.: Pan evaporation trends and the terrestrial water balance, 1, Principles and observations, Geogr. Compass, 3, 746-760, doi:10.1111/j.17498198.2008.00213.x, 2009.

Sivapalan, M., Takeuchi, K., Franks, S. W., Gupta, V. K., McDonnell, J. J., Mendiondo, E. M., O'Connell, P. E., Oki, T., Pomeroy, J. W., Schertzer, D., Uhlenbrook, S., and Zehe, E.: IAHS Decade on Predictions in Ungauged Basins (PUB) 2013-2012: shaping an exciting future for hydrological sciences, Hydrol. Sci. J., 48, 857-880, 2003.

Smith, P. J., Beven, K. J., and Tawn, J. A.: Detection of structural adequacy in process-based hydrological models: a particle-filtering approach, Water Resour. Res., 44, W01410, doi:10.1029/2006WR005205, 2008.

Sui, J. and Koehler, G.: Rain-on-snow induced flood events in southern Germany, J. Hydrol., 252, 205-220, 2001.

Teng, J., Vaze, J., Chiew, F. H. S., Wang, B., and Perraud, J.-M.: Estimating the relative uncertainties sourced from GCMs and hydrological models in modelling climate change impact on runoff, J. Hydrometeorol., 13, 122-139, doi:10.1175/JHM-D-11-058.1, 2012.

Vaze, J., Post, D. A., Chiew, F. H. S., Perraud, J.-M., Viney, N., and Teng, J.: Climate non-stationarity - validity of calibrated rainfallrunoff models for use in climate change studies, J. Hydrol., 394, 447-457, doi:10.1016/j.jhydrol.2010.09.018, 2010.

Vaze, J., Davidson, A., Teng, J., and Podger, G.: Impact of climate change on water availability in the Macquarie-Castlereagh river basin in Australia, Hydrol. Process., 25, 2597-2612, doi:10.1002/hyp.8030, 2011.

Wagener, T. M.: Can we model the hydrological impacts of environmental change?, Hydrol. Process., 21, 3233-3236, doi:10.1002/hyp.6873, 2007.

Wagener, T., Sivapalan, M., Troch, P. A., McGlynn, B. L., Harman, C. J., Gupta, H. V., Kumar, P., Rao, P. S. C., Basu, N. B., and Wilson, J. S.: The future of hydrology: an evolving science for a changing world, Water Resour. Res., 46, W05301, doi:10.1029/2009WR008906, 2010.

Woo, M. K., Kane, D. L., Carey, S. K., and Yang, D.: Progress in permafrost hydrology in the new millennium, Permafr. Perigl. Process., 19, 237-254, doi:10.1002/ppp.613, 2008.

Xu, C. Y., Widen, E., and Halldin, S.: Modelling hydrological consequences of climate change: progress and challenges, Adv. Atmos. Sci., 22, 789-797, 2005. 